\title{
Social cultural environment and public administration management based on the change of main social contradictions
}

\author{
Xiao Li \\ Heilongjiang Bayi Agricultural University, DaQing Heilongjiang, 163319, China \\ lixiao800828@163.com
}

Keywords: Main social contradictions, Social and cultural environment, Public administration.

Abstract: The main contents of the ethical norms of public administration are the supremacy of public welfare, harmful inaction, and careful use of power, social responsibility, equal competition and enhancement of trust. Contradiction is a philosophical category reflecting the unity of opposites within and between things, and is the core content of materialist dialectics. The main social contradiction is the one that occupies the core position and dominates the society. Administration itself is not the ultimate goal, it is a series of communication channels to convey people's needs and wishes, and to ensure that these needs and wishes can be reflected and considered through state control. Similarly, these channels also play the role of the government in conveying policies and implementing tasks to the people. Therefore, if these channels are to make positive and significant contributions to people-centered development, the role of administration must adapt to the social-cultural environment and tradition.

\section{Introduction}

The main social contradiction is the contradiction that occupies a central position and plays a dominant role in various fields of social life. The theory of major social contradictions is an important theoretical innovation made by the Chinese Communists in applying the contradiction theory of materialist dialectics to the reality of China's national conditions and leading the Chinese nation in the great practice of revolution, construction and reform [1]. The Chinese Communists have always attached great importance to the analysis of China's national conditions using the theory of major social contradictions, and regarded it as the realistic starting point and theoretical basis for China to formulate development policies at various stages of development [2]. Since the 1980s, the core orientation of the practice of western administrative system reform has been the socialization of public service. In the process of China's administrative system reform, government functions have been changing in stages with the development of productive forces, the change of major social contradictions, the change of political environment and the further requirements of public administration, Among them, "public service" has become the current focus and hot spot [3]. Administration itself is not the ultimate goal, it is a series of communication channels to convey 
people's needs and wishes, and to ensure that these needs and wishes can be reflected and considered through state control. Similarly, these channels also play the role of the government in conveying policies and implementing tasks to the people [4]. Therefore, if these channels are to make positive and significant contributions to people-centered development, the role of administration must adapt to the social-cultural environment and tradition [5]. Public ethics is a social spiritual value orientation with public rationality as the core, which directly determines the moral trend and spiritual construction of the social people [6]. The formation of the socialist market economy system has led to the decline of the spiritual value orientation of "nationalism" that prevailed under the planned economy in the past, and the spiritual value orientation of "individualism" that is in harmony with the Western humanistic background is difficult to fully transplant in China. Therefore, , The main content of the ethical norms of public administration is the supremacy of public welfare, harmfulness, careful use of power, social responsibility, equal competition, and trust. These norms laid the ethical foundation for public administration [7].

\section{Major social contradictions}

"Contradiction" and "main contradiction", as important propositions in the context of Chinese and western philosophy, have been favored and thought by many sages since ancient times. Marx, Engels and Lenin founded the materialist dialectics on the basis of critically absorbing the essence of predecessors' thoughts, and made many innovative views and explanations on the theory of "contradiction". Under the guidance of the basic principles of Marxism and in combination with China's actual conditions, the Chinese Communists have thoroughly summarized the Marxist contradiction theory and creatively put forward a brand-new theoretical system of "major social contradictions", which is used as a theoretical weapon to guide China's revolution, construction and reform."Main social contradiction" is understood literally, that is, the manifestation of the main contradiction in human society, or the main contradiction in human society [8]. Restricted by the evolutionary laws of history and the level of development of productive forces, human society is currently presented in the form of a large number of countries and nations. Different countries and nations have different levels of development, leading to different main social contradictions in their own countries or nations. Therefore, the main social contradiction here refers to the main social contradiction within each country or nation, not the main contradiction of the entire human society as a whole. In history, many thinkers have made many brilliant discussions on the level and characteristics of human needs. Aristotle, the ancient Greek philosopher, pointed out that there are three kinds of life: the first is to enjoy life, that is, the satisfaction of human physiological desire. The second is political life, which refers to people pursuing power and honor. The third is the life of contemplation, which refers to the life in which people pursue truth by using reason. American psychologist abraham maslow also divides people's needs from low to high into "physiological needs", "safety needs", "emotional and belonging needs", "respect needs" and "self-realization needs" as shown in Figure 1. 


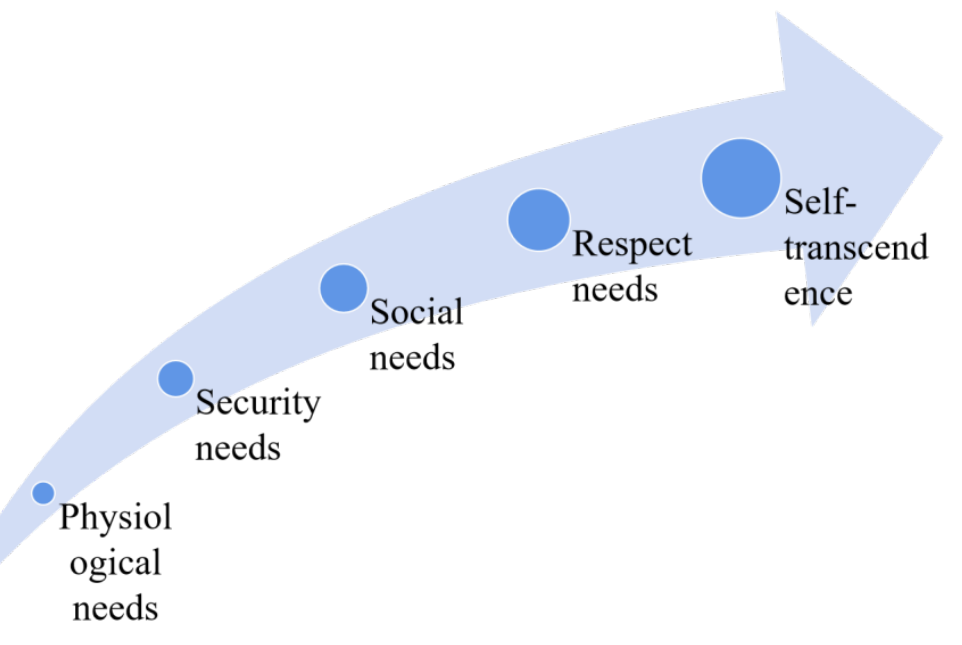

Figure 1: Maslow's hierarchy of needs theory

In the new era, China's economy has begun to shift from a stage of high-speed growth to a stage of high-quality development. The industrial structure, demand structure, and factor structure are all facing changes, which determines that the main contradictions of Chinese society in the new era need to be transformed. The report of the 19th National Congress of the Communist Party of China pointed out that the main contradiction in current Chinese society has been transformed into a contradiction between the people's growing need for a better life and unbalanced and inadequate development. The new era is an era of rapid economic development, endless high-tech emergence, and people's spiritual and material life. In view of the current "unbalanced and inadequate development" problem, China must build a modern economic system, take supply side structural reform as the core, solve the shortage of effective supply and optimize the structural reform and upgrading. Only by fully meeting the people's needs for a better life, realizing the balance and full development of various industries can we better realize the Chinese dream of great rejuvenation of the Chinese nation. The theory of major social contradictions is an important part of Chinese philosophy and social science research, and it is also the unique advantage of Chinese philosophy and social science research compared with foreign social science research. An in-depth study of the main contradictions in Chinese society in the new era can fully demonstrate the Chinese characteristics and style of philosophy and social science research, and at the same time add a theoretical wealth with Chinese style to the academic system of philosophy and social science in the world.

\section{The social and cultural environment and public administration of changes in the main social contradictions}

The social environment of administrative management generally refers to the economic environment, political environment and cultural environment of the country where the administrative system is located. It includes the status of social productivity and production relations at a certain historical stage, state system, political system, political party system, state structure form, and political order. And ideology, values, ethics, science and technology education level, etc. Social environment is the basis and premise for the survival and development of a country's administrative system, and the starting point and attribution of administrative activities. The transformation of the main social contradictions in China, on the one hand, shows that people's living standards have improved significantly and their yearning for a better life has become more intense. On the other hand, the crux of unbalanced and inadequate development has become increasingly prominent, which has 
become a "stumbling block" restricting the further development of China's economy and society. Only by deeply analyzing both sides of the contradiction can we prescribe the right medicine and formulate effective line, principles and policies. In recent years, China's administrative reform has been exploring along two basic directions: one is scientific, institutionalized, changeable and developmental. The other direction is social-cultural and rational. The former relies on modern management techniques such as data processing, quantitative textual research and bureaucratic forms, while the latter relies on various modes of human civilization and changes in cultural concepts. In the exploration of the second direction discussed, although the administrative staff also used some basic technical means, it is fundamentally qualitative and internal. At present, more and more people are acknowledging the statement that social-cultural functions and adaptability are more important than so-called "institutions" and technology. The traditional concept of "technical performance" seems to no longer be used when evaluating public administration. It is the first factor to be considered, and the one that receives the most attention should be the degree of satisfaction of the served. This view comes from the new concept of people-centered development. Hart further pointed out that "only with the collective efforts of the society will we pay special attention to those members who are in the most disadvantaged position, so that the minimum power, dignity, income and wealth of each member of the society can be guaranteed." As for how to achieve the goal of social equity through organizational structure design and management methods, Frederickson has sorted out the following table.

Table 1: Value, structure and management of social equity

\begin{tabular}{|c|c|c|}
\hline Pursue value & Structural design & Management method \\
\hline Responsiveness & $\begin{array}{c}\text { Decentralization (politics and } \\
\text { administration): contract. } \\
\text { Neighborhood control over street } \\
\text { bureaucrats }\end{array}$ & $\begin{array}{c}\text { Routine interactions between customers, } \\
\text { employees, and managers. The definition of } \\
\text { democratic management should include not only } \\
\text { responding to elected bureaucrats, but also } \\
\text { responding to interest groups and unorganized } \\
\text { minorities: training }\end{array}$ \\
\hline $\begin{array}{l}\text { Participation of } \\
\text { employees and citizens } \\
\text { in decision-making }\end{array}$ & $\begin{array}{c}\text { Empower neighborhood } \\
\text { committees: overlapping work } \\
\text { groups: employee participation in } \\
\text { the decision-making process }\end{array}$ & $\begin{array}{c}\text { Acceptance of a criterion that insists on the right } \\
\text { of employees and citizens to participate in the } \\
\text { decision-making process that directly affects } \\
\text { their lives: training for organizational } \\
\text { development }\end{array}$ \\
\hline Socia & \begin{tabular}{|c|} 
A large-scale fiscal and \\
decentralization system. Fair \\
output and results of public \\
services dominated by all classes \\
of society
\end{tabular} & $\begin{array}{l}\text { Professional ethics standards for social fairness. } \\
\text { The principle followed by management, that is, } \\
\text { the principle of majority decision does not } \\
\text { deprive a minority of the right of equal access to } \\
\text { public services }\end{array}$ \\
\hline Citizen choice & $\begin{array}{c}\text { Modify the service selection } \\
\text { method to expand the selection } \\
\text { opportunities. Overlapping design } \\
\text { (provided by the service). contract }\end{array}$ & $\begin{array}{l}\text { Reduce the monopoly management of specific } \\
\text { services such as medical or education }\end{array}$ \\
\hline $\begin{array}{l}\text { Administrative } \\
\text { responsibility for the } \\
\text { effectiveness of the } \\
\text { project }\end{array}$ & $\begin{array}{l}\text { Decentralization: Delegation: } \\
\text { Performance Target }\end{array}$ & $\begin{array}{c}\text { Not only from general organizational standards, } \\
\text { but also from the perspective of all social classes } \\
\text { to evaluate organizational performance. For } \\
\text { whom to evaluate performance? }\end{array}$ \\
\hline
\end{tabular}

For the understanding of modern society, we can roughly understand that market refers to the influence of economic system on people, which mainly restricts human behavior or life through 
money. The administrative organ means that the government influences people's behavior through the power generated by the bureaucratic administrative structure. It can be said that money and power are the two main media that restrict people's behavior in modern society. At present, the United States is mainly responsible for market supervision functions such as the Federal Trade Commission, the Federal Communications Commission, the Federal Energy Regulatory Commission, the Consumer Product Safety Commission, the Food and Drug Administration, and the Environmental Protection Agency. In addition, the Anti-monopoly Department of the Ministry of Justice, the Food Safety Inspection Bureau of the Ministry of Agriculture, and the Occupational Safety and Health Administration of the Ministry of Labor also undertake some anti-monopoly, food safety supervision and occupational safety supervision functions, as shown in Table 2.

Table 2: The establishment of some market regulatory agencies in the United States (federal level)

\begin{tabular}{|c|c|}
\hline Organization Type & Institution name \\
\hline \multirow{6}{*}{ Independent Regulatory Commission } & Federal Trade Commission (FTC) \\
\hline & Consumer Product Safety Commission (CPSC) \\
\hline & Federal Communications Commission (FCC) \\
\hline & Federal Energy Regulatory Commission (FERC) \\
\hline & Commodity Futures Trading Commission (CFTC) \\
\hline & Environmental Protection Agency (EPA) \\
\hline \multirow{4}{*}{$\begin{array}{c}\text { Subordinate agencies of the Cabinet } \\
\text { Department }\end{array}$} & Food and Drug Administration (FDA) \\
\hline & Antitrust Department (AD) of the Ministry of Justice \\
\hline & $\begin{array}{c}\text { Department of Labor Occupational Safety and Health } \\
\text { Administration (OSHA) }\end{array}$ \\
\hline & $\begin{array}{l}\text { Food Safety Inspection Service (FSIS), Ministry of } \\
\text { Agriculture }\end{array}$ \\
\hline
\end{tabular}

Administration is to find out a social structure or form suitable for human existence. Under such a premise, every administrative reform should presuppose the meaning of the corresponding sociocultural context, which is bound to make it possible for the corresponding administrative reform to achieve results. Society is a human society. All kinds of human behaviors constitute a wider social environment. The formation of any social system is the result of human behaviors.

\section{Conclusions}

Since the birth of human society, the main social contradictions have always followed, and they have always constituted a theme of social politics, economics and cultural life. The correctness of the judgment of the main social contradictions directly determines the development direction of a country and society, and even affects the rise and fall of a country or nation. In view of this, the study of the main contradictions in society is the academic mission that every generation of scholars should shoulder. On the cultural level, the interaction between public administration and the public is not only dependent on cultural materials and cultural media, but also in the process of communication, we should pay attention to the knowledge of simultaneous transmission and renewal of culture. On the social level, administrative management behavior not only regulates different opinions or social behaviors, but also promotes social integration and human sense of belonging. As for personality, administrative actions should achieve the function of social education and promote the healthy development of individual self-concept. If the administrative theory is applied to the practice of 
administrative management, it can help to realize the above functions or solve the problems, and the guiding significance of the administrative theory will be reached.

\section{References}

[1]. Wu Yun, Xie Xinshui. Defining the main body of policy supply in the field of people's livelihood under the background of the transformation of main contradictions: an analysis based on government trust data [J]. Party and Government Research, 2019, 154(01): 96-106.

[2]. Wu Rong. The new requirements for social governance in the transformation of major contradictions in Chinese society [J]. Northern Economy, 2019, No.384(11): 71-74.

[3]. Zhao Ke. Reshaping the administrative culture of local government under the new public service theory [J]. Journal of Tianshui School of Administration, 2017, 000(004): 23-25.

[4]. Qiao Lu. Discussion on the impact of administrative environment on administrative management [J]. Management Observation, 2018, 704(33): 84-85.

[5]. Gao Hongcun. Renewal of ideas drives innovation in rural communities' public cultural services [J]. Administrative Management Reform, 2019, 117(05): 29-31.

[6]. Huang Yongtao. China's administrative reform from the perspective of new public management [J]. Management Observation, 2019, 717(10): 89-91.

[7]. Zhang Hui, Zhuge Shanbing. The construction of a social and cultural environment based on the regional sports event innovation network [J]. Zhejiang Sports Science, 2019, 41(01): 29-33.

[8]. Liu Weihua. The influence of social and cultural environment on the inheritance and development of traditional sports culture in Miao villages in western Hunan [J]. Ethnic Forum, 2018, No.396(02): 83-87. 